\title{
Gingival Myiasis on Oral Squamous Cell Carcinoma in Turkey: A Case Report
}

\section{Oral Squamöz Hücreli Karsinom Zemininde Gelişen Miyaz Olgusu}

\author{
(D) Banuçiçek Yücesan ${ }^{1}$, (10 Cahit Babür², (D) Nafiye Koç3, (1) Selçuk Killı̧4 \\ ${ }^{1}$ Çankırı Karatekin University Faculty of Health Sciences, Healthcare Management, Department of Control of \\ Zoonotic Diseases, Çankırı, Turkey \\ ${ }^{2}$ Public Health General Directotare of Turkey, National Parasitology Referance Laboratory, Ankara, Turkey \\ ${ }^{3}$ Ankara University Faculty of Veterinary Medicine, Department of Protozoology and Entomology, Ankara, Turkey \\ ${ }^{4}$ University of Health Sciences Turkey Gülhane Faculty of Health Sciences, Department of Chemical Biological \\ Radiological Nuclear, Ankara, Turkey
}

Cite this article as: Yücesan B, Babür C, Koç N, Kilıç S. Gingival Myiasis on Oral Squamous Cell Carcinoma in Turkey: A Case Report. Turkiye Parazitol Derg 2021;45(2):160-163.

\begin{abstract}
Myiasis is a disease caused by tissue invasion of diptera larvae and eggs. Oral myiasis is mostly related to old age, poor oral hygiene, suppurative lesions, anatomical disorders and cancer cases. Oral squamous cell carcinoma (OSCC) is an important risk factor for myiasis. This report presents the case of an 82-year-old woman who presented with gingival myiasis developing on the background of OSSC. The patient was diagnosed with OSSC in the hospital. Myiasis larvae were identified and sent to the National Parasitology Reference Laboratory for identification. Thus, development of myiasis on OSCC background was shown in Turkey for the first time. Myiasis larvae have been identified as the $3^{\text {rd }}$ phase of the larvae Sarcophaga sp. development (Diptera: Sarcophagidae). As a result, myiasis cases are sporadic in Turkey, and it can be avoided by controlling fly population and by paying attention to hygiene. Controlling myiasis is an important public health problem and should be considered in a single health concept, as it causes health problems in both humans and animals. The findings of this case will draw attention to the importance of dealing with myiasis factors, which is a public health problem.
\end{abstract}

Keywords: Larvae, myiasis, oral squamous cell carcinoma, Sarcophaga sp.

Öz

Miyaz, diptera larva ve yumurtalarının doku istilasından kaynaklanan bir hastalıktır. Oral miyaz nadir görülen, yaşllılı, zayıf ağız hijyeni, süpüratif lezyonlar ve kanser olguları ilgili bir durumdur. Oral skuamöz hücreli karsinom (OSCC) miyazda önemli bir risk faktörüdür. Bu raporda, 82 yaşında bir kadın hastada OSCC zemininde gelişen miyaz sunulmuştur. Hasta, ağız içinde ovoid bir lezyon ile diş hekimine müracaat etmiş, sonra hastanede OSSC tanısı konmuş ve bu zeminde miyaz larvaları tespit edilmiştir. Larvalar Ulusal Parazitoloji Referans Laboratuvarı'na gönderilmiştir. Laboratuvar çalışmaları ile tespit edilen larvaların üçüncü dönem Sarcophaga sp. (Diptera: Sarcophagidae) larvaları olduğu tanımlanmıştır. Böylece, Türkiye'de ilk defa OSCC zemininde gelişen miyaz olgusu gösterilmiştir. Sonuç olarak, Türkiye'de miyaz sporadiktir ve sinek popülasyonunu kontrol ederek ve hijyene dikkat edilerek önlenebilir. Miyaz ile mücadele bir halk sağlığı sorunudur. İnsanlarda ve hayvanlarda karşılaşıldığından tek sağlık kavramı içinde değerlendirilmelidir. Bu olgu sunumu ile, bir halk sağlığı problemi olan miyaz etkenleri ile mücadeleye önem verilmesinin üzerinde durulması amaçlanmıştır.

Anahtar Kelimeler: Larva, miyaz, oral skuamöz hücreli karsinom, Sarcophaga sp.

\section{INTRODUCTION}

Myiasis is a parasitic infestation of human/animal tissues and cavities with dipterous larvae and eggs. The term myiasis is derived from the Greek words "myia," which means fly and "iasis," which means disease. This term was first proposed by Hope in 1840 (1) and oral myiasis was first defined by Laurence in 1909 (2,3). The clinical menifastations of myiasis depend on the fly species, the invasion level and stage of the larvae and the infestation area. Flies that cause myiasis belong to the class of Insecta, order Diptera, and are classified into seven different families (calliphoridae, 
sarcophagidae, oestridae, hypodermatidae, gasterophylidae, glossinidae and muscidae), which can infest the skin and body cavities. Myiasis is divided into three groups; i- obligatory (the larvae can affect undamaged skin and require a living host for their development), ii- facultative (free living larvae capable to initiate myiasis to destroy nectoric tissue), iii- accidental (free living larvae which cause myiasis when the larvae are injested accidentally). Myiasis can be also classified according to the anatomical area of infestation; i- cutaneous myiasis, ii- myiasis of external orifices, iii- visceral myiasis. In addition, it can be divided clinically into; i- primary and ii- secondary myiasis. Myiasis most often occurs in the skin wounds, nose, eyes, sinuses, ears, and vagina. Occasionally, it can be observed seen in the mouth $(2,4,5)$. Sarcophaga sp. is a member of the Sarcophagidae family and a known group of flies which cause myiasis in Europe and Turkey. They are called flesh flies, and their adults are twice the size of house flies. These flies generally leave their eggs or larvae in the nasal cavity and cause myiasis on living tisues. In this study, we present a case of Sarcophaga sp. myiasis seen in the oral cavity.

\section{CASE REPORT}

An 82-year-old female patient visited a dentist with a complaint of a tongue wound. The patient was directed to the hospital by dentist due to the complicated apperance of the wound, and there was indications for a poor oral hygiene. A moderately sized lesion was observed in the patient's mouth. On physical examination, an ovoid lesion of approximately $4 \mathrm{~cm}$ was detected in the right half of the sublingual region that crosses the midline and not descends to the floor of the mouth. Induration around the lesion and fixed lymph nodes of $1 \mathrm{~cm}$ in the left upper jugular, $1 \mathrm{~cm}$ in the middle jugular, and approximately $3 \mathrm{~cm}$ in the right upper jugular were detected by palpation. A biopsy of the lesion showed that the patient was suffering from a well-differentiated squamous cell carcinoma. After debridement of the lesion, a large number of larvae were detected within the lesion. Two larvae removed alive from the lesion were sent to the parasitology laboratory for examination, where they were identified as the third instar larvae of Sarcophaga sp. using standart taxonomic keys $(6,7)$.

For this identification, microscopic preparations were prepared by dissection of the cephalopharyngeal skeleton and anterior and posterior stigmas of the larvae. The shape, number and order of larval segments, peritemes and perithem buttons were evaluated morphologically. It was determined that the larvae were $10-12 \mathrm{~mm}$ in size and consisted of 12 segments, which were seen as transverse spiral bumps (Figure 1A). The back end of the Sarcophaga sp. larvae had a pit-like structure that enclosed the posterior stigmas. The posterior stigmas consisted of three long slits, while the middle one was straight and the others were curved $(6,7)$ (Figure 1B, C).

It was observed that the anterior stigmas extending from the lateral surfaces of the second segment were small and had a fan-like structure consisting of 13 branches, while the cephalopharyngeal skeleton was typical to Sarcophaga sp. $(6,7)$ (Figure 2A, B).

In the literature, local application of various substances such as ivermectin, turpentine oil, mineral oil, ether, chloroform, ethyl chloride, mercury chloride, creosote, saline, phenol, calomel, olive oil, iodoform are recommended for the control of larvae. In addition, it is necessary to apply treatments that prevent the development of secondary bacterial infection in the skin

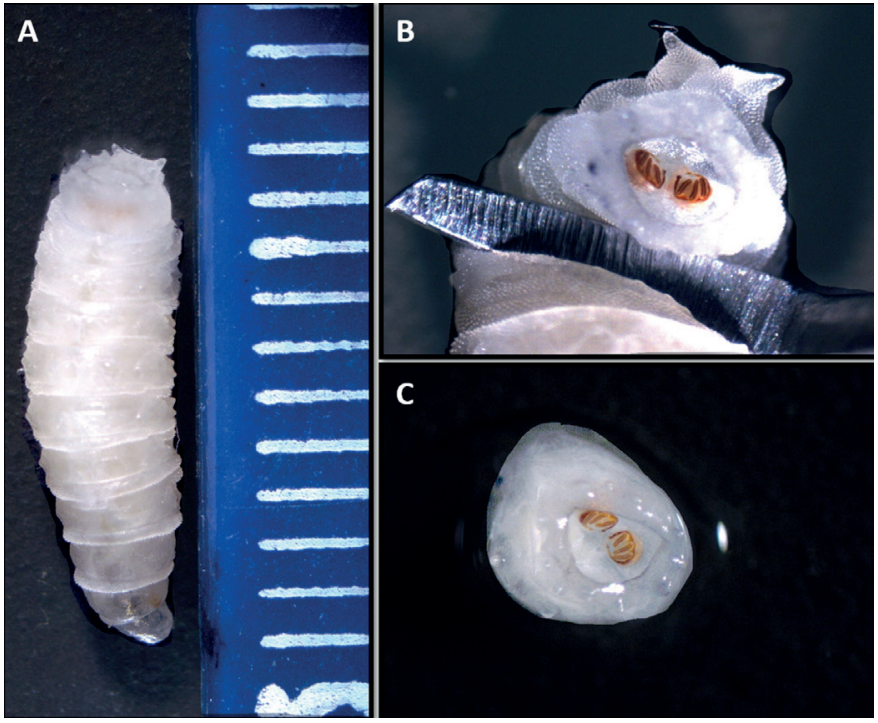

Figure 1. A) Sarcophaga sp. $3^{\text {rd }}$ stage larvae, B, C) Posterior stigmas (posterior spiralce)

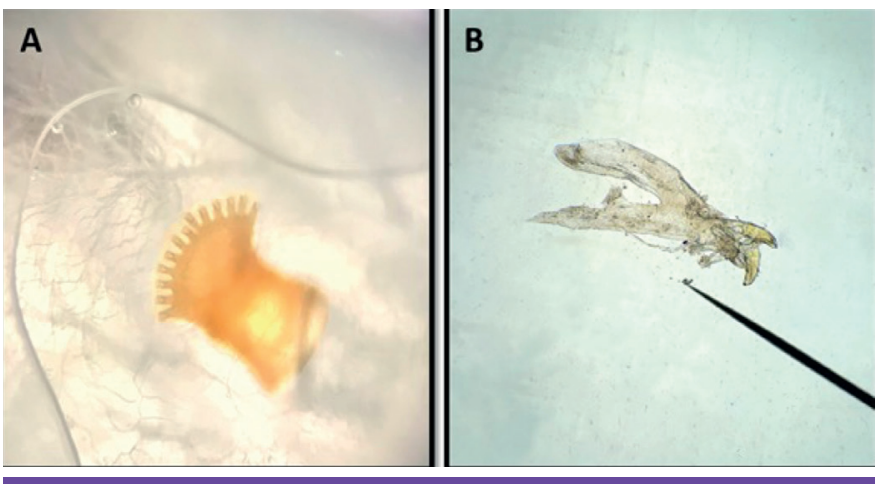

Figure 2. A) Anterior stigmas (anterior spiracles), B) Cephalopharyngeal skeleton

surrounding the lesion where myasis agents are located. In the present case, the larvae were physically removed from the wound once a day until they were completely cleaned, and antibiotic treatment was initiated in terms of infection while the patient was being treated for cancer. However, the patient's condition deteriorated soon and she died thereafter.

\section{DISCUSSION}

Myiasis is a parasitic invasion of tissues by living larvae, usually seen in tropical and subtropical countries, and often caused by poor hygiene (8). Myiasis particularly affects the elderly humans and develops also secondary to poor alcoholism, and suppurative lesions (9). After the female flies lay their eggs on the damaged tissues, the larvae can settle in the deep tissues. Cases of myiasis in the mouth and nasal cavity can cause dangerous complications which can result even with death. Larval infestation causes progressive destruction and cavitation and ultimately adheres tightly, forming a fibrous capsule that causes difficulties in dissection during surgery (10). The severity of tissue destruction depends on the number of larvae that settle in the host tissue.

Although oral myiasis is mostly seen in tropical countries, it can also occur in temperate climates when oral hygiene is inadecvate and in immuno-surpressed patients. It is known that patients with suppurative lesions, severe bad breath, facial trauma, 


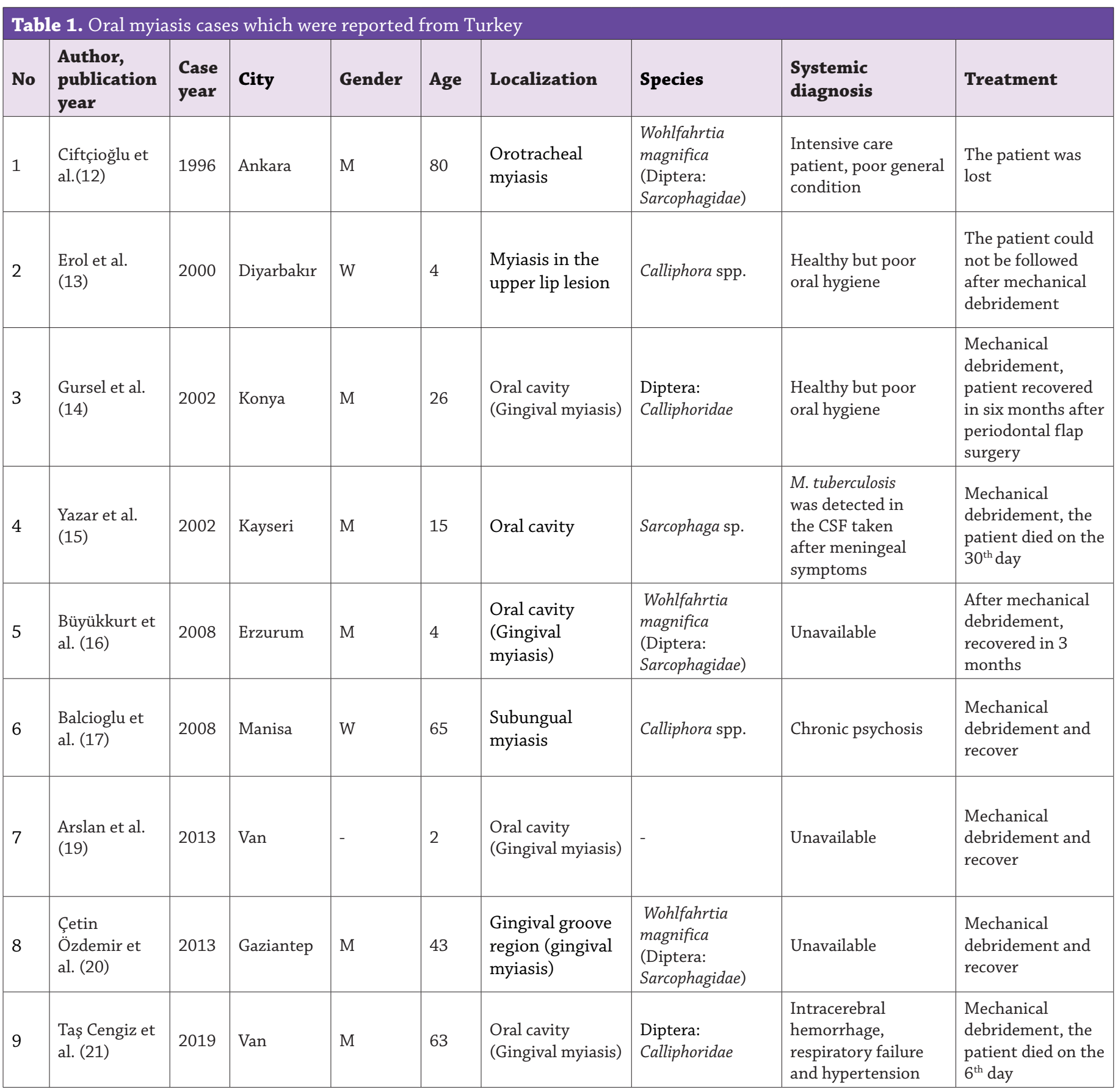

persistent mouth opening, thumb sucking habits and advanced periodontal diseases, lesions in tooth extraction areas, fungal infections of the buccal mucosa, oral carcinomas and epilepsy are susceptible to oral myiasis (11).

In Turkey, nine oral myiasis cases were reported (12-22) (Table 1), showing that kind of myiasis was mainly observed in the elderly and younger ages.

Cases of myiasis developing in different types of carcinoma have been reported worldwide (22-32). The most common malignant lesion in the head and neck region is squamous cell carcinoma (SCC) (33). Oral SCC (OSCC) is a possible risk factor for myiasis for humans or other mammals. In oral myiasis cases, larvae can cause itching and irritation, as well as cause serious and sometimes lifethreatening bleeding by destroying vital tissues. With this article a myiasis case is reported in developing OSCC ground for the first time in Turkey. Myiasis occurring on OSCC background were reported five times from India and four from Brazil $(24,25)$.

Prevention is based on the fight against adult flies. Limiting myiasis is an important issue for public health. Poor health conditions and insufficient sanitation are important risk factors for myiasis, especially in underdeveloped countries with low socioeconomic status. It is very important for people living in endemic areas to not leave their wounds open and avoid sleeping outdoors. Physicians should consider clinical examinations in terms of myiasis during the months of May-October, when the fly population is intense throughout our country. In addition, it is known that myiasis can be significantly reduced by informing the people in the regions dealing with animal husbandry, training the personnel who are interested in wound care in health units or hospitals, and combating the factors. 


\section{INFORMATION}

This study was presented as a poster at $38^{\text {th }}$ International Turkısh Microbiology Congress (04-08 November 2018 Antalya, Turkey).

\section{* Ethics}

Informed Consent: Since the patient was lost when myiasis was identified, the patient's approval could not be obtained.

Peer-review: Externally and internally peer-reviewed.

\section{** Authorship Contributions}

Concept: B.Y., Design: B.Y., C.B., Data Collection or Processing: B.Y., C.B., N.K., Analysis or Interpretation: B.Y., C.B., N.K., S.K., Literature Search: B.Y., Writing: B.Y.

Conflict of Interest: No conflict of interest was declared by the authors.

Financial Disclosure: The authors declared that this study received no financial support.

\section{REFERENCES}

1. Hope FW. On insects and their larvae occasionally found in human body. Royal Entomol Soc Trans 1840; 2: 236-71.

2. Reddy MH, Das N, Vivekananda MR. Oral myiasis in children. Contemp Clin Dent 2012; 3(Suppl 1): 19-22.

3. Shikha S, Prasad Guru R, Ashutoshdutt P, Meenakshi S. Oral Myiasis: A Rare Case Report and Literature Review. J Dent (Tehran) 2015; 12: 456-9.

4. Daldal N, Atambay M. Myiasis (Miyaz). In: Özcel MA editör. Özcel'in Tıbbi Parazit Hastalıkları, 1. Baskı Türkiye Parazitoloji Derneği yayınları, İzmir. 2007. p. 867-81.

5. Yenice MG, Demir T, Babür C, Nalbantoğlu S, Kıllı̧ S. Psychoda albipennis' in (Diptera: Nematocera) neden olduğu ürogenital miyazis olgusu [A case of urogenital myiasis caused by Psychoda albipennis (Diptera: Nematocera)] Mikrobiyol Bul 2011; 45: 558-64.

6. Amnedt J, Goff ML, Campobasso CP, Grassberger M. Current Concepts in Forensic Entomology, Springer, Newyork: 2009.

7. Zumpt F. Myiasis In Man And Animals İn The Old World: A Textbook for Physicians, Veterinarians and Zoologist. 1st ed. Butterworths, London: 1965.

8. Lazaro SA, Yépez FDG, De Carli JP, Trentin MS, Dogenski LC, De Conto F. Treatment of facial myiasis in an elderly patient with oral squamous cell carcinoma: Case report. Int J Surg Case Rep 2020; 71: 260-5.

9. Corrêa AP, Beneti IM, Ribeiro ED, Pereira CC, Souza FÁ, Garcia-Júnior IR. Myiasis in elderly involving oral and nasal cavities-diagnosis and treatment. J Craniofac Surg 2015; 26: 989-90.

10. Kumar SL, Manuel S, John TV, Sivan MP. Extensive gingival myiasis Diagnosis, treatment, and prevention. J Oral Maxillofac Pathol 2011; 15: 340-3.

11. Ansari TR, Ørner RJ. Bagh regrows - earthquake survivors as catalysts of community and personal reconstruction. Int Psychiatry 2008; 5: 97-100.

12. Ciftçioğlu N, Altintaş K, Haberal M. A case of human orotracheal myiasis caused by Wohlfahrtia magnifica. Parasitol Res 1997; 83: 34-6.

13. Erol B, Unlü G, Balci K, Tanrikulu R. Oral myiasis caused by hypoderma bovis larvae in a child: a case report. J Oral Sci 2000; 42: 247-9.

14. Gursel M, Aldemir OS, Ozgur Z, Ataoglu T. A rare case of gingival myiasis caused by diptera (Calliphoridae). J Clin Periodontol 2002; 29: 777-80.

15. Yazar S, Dik B, Yalçin S, Demirtaş F, Yaman O, Oztürk M, et al. Nosocomial Oral Myiasis by Sarcophaga sp. in Turkey. Yonsei Med J 2005; 46: 431-4.
16. Büyükkurt MC, Miloğlu Ö, Nalbantoğlu S, Uslu H, Yolcu Ü, Aktaş O. Oral myiasis in a child due to Wohlfahrtia magnifica: Original Image. Turkiye Klinikleri J Med Sci 2008; 28: 782-5.

17. Balcioğlu IC, Ecemiş T, Ayer A, Ozbel Y. Subungual myiasis in a woman with psychiatric disturbance. Parasitol Int 2008; 57: 509-11.

18. Kara M, Arslan MÖ. Kuzeydoğu Anadolu'da hayvanlarda ve insanlarda myiasis. Atatürk Üniversitesi Vet Bil Derg 2011; 6: 245-50.

19. Arslan S, Islamoğlu A, Çobanoğlu B. A rare case of gingival myiasis in a 2-year-old child. Int J Paediatr Dent 2013; 23: 387-8.

20. Çetın Özdemır E, Ekşi F, Şenyurt SZ, Üstün K, Karaoğlan İ, Ercıyas K. Wohlfahrtia magnifica'dan kaynaklanan gingival miyaz olgusu [A case of gingival myiasis caused by Wohlfahrtia magnifica]. Mikrobiyol Bul 2014; 48: 512-7.

21. Taş Cengiz Z, Yılmaz H, Beyhan YE, Yakan Ü, Ekici A. An Oral Myiasis Case Caused by Diptera (Calliphoridae) Larvae in Turkey. Turkiye Parazitol Derg 2019; 43: 213-5.

22. Berger S. Infectious Diseases of Turkey. 2019. Available from: https://books.google.com.tr/books?id=xbWHDwAAQBAJ $\& p g=P A 275 \& l p g=P A 275 \& d q=$ oral + myiasis +turkey\&source $=\mathrm{bl} \&$ ots $=\mathrm{me} 7 \mathrm{AVjzU} 2 \mathrm{O} \& \mathrm{sig}=\mathrm{ACfU} 3 \mathrm{U} 32-\mathrm{CevsMLDP7h} 8 \mathrm{Xg}$ Q1kyXvoN 72pw\&hl=tr\&sa =X\&ved $=2 \mathrm{ahUKE}$ wihx-H9wZ3 qAhVNe8AKHZuYApoQ6AEwB3oECAoQAQ\#v=onepage\&q=oral\%20 myiasis\%20turkey\&f=false. 2019 edition. Gideon Informatics, Inc, Dr. Stephen Berger (access date 25.06.2020).

23. Biradar S, Wankhede P, Munde A, Shaikh S. Extensive Myiasis infestation associated with Oral Squamous Cell Carcinoma: Report of two cases. Dent Res J (Isfahan) 2015; 12: 100-5.

24. Al-Maweri SA, Al-Sufyani GA, Tarakji B, Abdulrab S. Myiasis Associated with Oral Squamous Cell Carcinoma--A Literature Review. Asian Pac J Cancer Prev 2015; 16: 4997-9.

25. Jain A. Myiasis in patients with oral squamous cell carcinoma-a systematic review and protocol for management. Oral Maxillofac Surg 2019; 23: 2659.

26. Patel BC, Ostwal S, Sanghavi PR, Joshi G, Singh R. Management of Malignant Wound Myiasis with Ivermectin, Albendazole, and Clindamycin (Triple Therapy) in Advanced Head-and-Neck Cancer Patients: A Prospective Observational Study. Indian J Palliat Care 2018; 24: 459-64.

27. Carvalho RW, Santos TS, Antunes AA, Laureano Filho JR, Anjos ED, Catunda RB. Oral and maxillofacial myiasis associated with epidermoid carcinoma: a case report. J Oral Sci 2008; 50: 103-5.

28. Pessoa L, Galvão V. Myiasis infestation in advanced oral squamous cell carcinoma. BMJ Case Rep 2011; 2011: 0420114124

29. Dharshiyani SC, Wanjari SP, Wanjari PV, Parwani RN. Oral squamous cell carcinoma associated with myiasis. BMJ Case Rep 2012; 2012: 2012007178.

30. Girardi FM, Scrofernecker ML. Myiasis in patients with head and neck cancer: Seldom described but commonly seen. Ear Nose Throat J 2017; 96: 19-22.

31. de Arruda JAA, de Oliveira Silva LV, Silva PUJ, de Figueiredo EL, Callou G, Mesquita RA, et al. Head and neck myiasis: a case series and review of the literature. Oral Surg Oral Med Oral Pathol Oral Radiol 2017; 124: 249-56.

32. Biswas S, McNerney P. Myiasis on a Giant Squamous Cell Carcinoma of the Scalp: A Case Report and Review of Relevant Literature. World J Oncol 2016; 7: 34-9.

33. Chegini S, Mitsimponas K, Shakib K. A review of recent advances in histopathological assessment of head and neck squamous cell carcinoma. J Oral Pathol Med 2020; 49: 9-13. 